\title{
Overweight and obesity in preschoolers: Prevalence and relation to food consumption
}

\author{
Aretha Matos de Araujo ${ }^{1}$, Socorro Adriana de Sousa Meneses Brandão², Marcos Antônio da Mota Araújo³, \\ Karoline de Macêdo Gonçalves Frota ${ }^{4 *}$, Regilda Saraiva dos Reis Moreira-Araujo 4

Study conducted by Graduate Food and Nutrition Program, Department of Nutrition, Universidade Federal do Piaú (UFPI), Teresina, PI, Brazil

Article received: 5/31/2016 Accepted for publication: 6/20/2016

*Correspondence: Departamento de Nutrição, UFP Address: Campus Universitário Ministro Petrônio Portela, s/n, bl. 13, Teresina, PI - Brazi

Postal code: $64049-550$ karolfrota@ufpi.edu.b

http://dx.doi.org/10.1590/1806-9282.63.02.124

\section{SUMmARY}

Objective: To determine overweight and obesity prevalence in preschool children from public education, and to determine their relation to food consumption. Method: Cross-sectional study with children aged between 2 and 5 years, of both sexes, enrolled at municipal day care centers. Socioeconomic, demographic and anthropometric data were collected, in order to calculate the body mass index (BMI) for age. Data on food consumption were assessed using a Food Frequency Questionnaire. $\chi^{2}$ test, Kruskal-Wallis test, Student's t-test and Pearson's correlation were used at a significance level of $5 \%$.

Results: Of 548 children, $52 \%$ were male, with mean age of 4.2 years old. Most families had incomes between 1 and 2 minimum wages (59.7\%), in addition to 10 years (mothers) of education. Anthropometric parameters did not differ significantly between sexes. According to the BMI-for-age, it was found that most of children were well-nourished (85.2\%), 8.2\% had the risk of becoming overweight, and $4.2 \%$ were overweight. The most consumed foods were: rice (100\%), beans (99.4\%), bread (98.5\%), fruit (98.5\%), red meat (97.1\%), butter and margarine (95.4\%), biscuits, cakes and sweet pies (94.1\%), dairy products (94.1\%), chocolate milk (91.7\%), and soft drinks (90.2\%). Consumed foods that were strongly correlated $(r>0.7)$ to the risk of/excess weight were, as follows: bread; biscuits, cakes, sweet pies; dairy products; chocolate milk; sausages.

Conclusion: There was low prevalence of overweight and absence of obesity among the population assessed. The risk of overweight was greater among girls. Data from the study showed deviations in food consumption.

Keywords: overweight, obesity, preschooler, food consumption.

\section{INTRODUCTION}

The change in the nutritional profile of Brazilian children due to the nutritional transition has revealed the increasing prevalence of overweight and obesity among children, in parallel to the reduction of nutritional deficits, and this situation has become alarming due to rising indicators. ${ }^{1}$

Estimates by the World Health Organization (WHO) suggest that excess weight affects around 5 million children aged under 5 years worldwide. ${ }^{2}$ The Family Budget Survey (POF, in the Portuguese acronym) 2008-2009 showed an important increase in the number of obese children in Brazil, with a prevalence of $32.8 \%$ overweight and $16.2 \%$ obesity among children up to 5 years of age. ${ }^{3}$

The growing trend of overfeeding, overweight and obesity means the prevention of these outcomes is of the utmost priority in order to prevent complications in adult life, considering the multifactorial nature of this condition.., 5

The first years of life are sensitive to nutritional changes and metabolic disorders, and it is a critical period for establishing habits and behaviors that will influence both growth and child development. ${ }^{6,7}$

Therefore, assessment of the composition of the diet of preschoolers has become an extremely relevant point, 
considering the impact that consumption can have on the overall health of this age group, preventing imbalances both due to deficiency diseases and dietary excess. ${ }^{8}$

Faced with the increasing prevalence of overweight and obesity, as well as changes in food consumption among preschool children, it is necessary to obtain representative data for this population, which is exposed to this risk the most often, in order to enable further follow-up, monitoring and intervention measures, whenever these become necessary. Therefore, this study aimed to verify the prevalence of overweight and obesity in preschoolers at public education institutions in Teresina, capital of the Brazilian state of Piauí, and its relationship to food consumption.

\section{Method}

This is a cross-sectional and analytical study, in which we assessed preschoolers of both sexes aged 2 to 5 years and enrolled in the Municipal Public Education Network of Teresina, in the Brazilian state of Piauí, from the four census regions of the city. The day care centers were defined by means of drawing lots, as well as the sample population.

For calculation of the sample size (n), a $10 \%$ prevalence of overweight and obesity was adopted, as observed in a study with Brazilian children of low socioeconomic status, ${ }^{9}$ obtaining $\mathrm{n}=548$ children, considering a margin of error (e) of $5 \%$ and a confidence level of $95 \%$.

To begin the collection of data, the approval of the Ethics Committee of the Federal University of Piauí (Report No. 94772/12), the Department of Education and the parents/guardians of the students was obtained by signing the informed consent form, in addition to obtaining the Consent of Participation of Person as a Subject.

The inclusion criterion was the absence of physical or motor restrictions that could impair the collection of anthropometric data.

We collected and recorded data relating to the general conditions and health of the child, such as age, sex, birth weight, current height and weight, time attending day care, the occurrence of diseases, control of parasitosis and the use of vitamins and medicines, socioeconomic data (level of education and parental occupation, household income, number of family members, number of rooms in the house, basic sanitation and type of housing) as well as an anthropometric assessment with measurement of body weight and stature. The anthropometric measurements were determined using standard techniques. ${ }^{10,11}$ To measure the weight, a pre-calibrated Wiso W910 ultra slim digital scale with capacity for $150 \mathrm{~kg}$ and graduation in units of $100 \mathrm{~g}$ was used, and a WCS ${ }^{\circledR}$ stadiometer, with measurements in triplicate.

The weight and height data were used to calculate the body mass index (BMI), which was then adjusted for age in the Z-score using the WHO's growth curves. ${ }^{2}$ The WHO criteria were used to classify the nutritional status, ${ }^{12}$ as well as that adopted by the Brazilian Ministry of Health, ${ }^{13}$ which was BMI for age, using the Anthropometric Program ANTHRO. ${ }^{14}$

Food consumption of the preschoolers was verified using a previously validated qualitative Food Frequency Questionnaire (FFQ) completed by the child's guardian or parent. ${ }^{15}$ Foods were categorized with the following consumption frequencies: consumes versus does not consume. The "consumes" category included consumption when this occurred daily, weekly or fortnightly. The "does not" category included monthly consumption or just non-consumption. The questionnaire included foods consumed regionally and the usual food for this population.

For the statistical analysis a database was created using Statistical Package for the Social Sciences, software version 17.0. ${ }^{16}$ The results were presented using simple and cross-frequency tables, with absolute values, percentage, means and standard deviations, when necessary. In order to verify the association, Chi-square $\left(\chi^{2}\right)$ test was applied on the nominal variables and the Kruskal-Wallis test was used to test differences in proportions. Student's t-test was applied to the numerical variables (age, weight, height). Pearson correlation was used in the Food Frequency in relation to nutritional state. Significance of 5\% was adopted for all tests $(\mathrm{p}<0.05) .{ }^{17}$

\section{Results}

The sample was composed of 548 preschoolers aged between 2 and 5 years originating from day care centers located in the city's four zones. Fifty-two percent of the participants were male and $48 \%$ female, without a significant difference in the $\chi^{2}$ test, as per Table 1 .

It can also be noted in Table 1 that the average age was 4 years and 2 months, and there was no significant difference ( $\mathrm{p}=0.874$ ) between age and sex. The birth weight was around $3.169 \mathrm{~kg}$ in the group of children studied and the average time enrolled at the school was 1 year and 6 months.

With respect to the current weight, boys presented a mean of $17.1 \mathrm{~kg}$, and the girls a mean of $16.7 \mathrm{~kg}$. The mean current height among the boys was $105 \mathrm{~cm}$ and $104 \mathrm{~cm}$ among the girls. No significant difference was observed in the height and weight in relation to sex ( $p>0.05)$. 
The average was five people per family. Regarding the mother and father's level of education, the average time of education of the mother was around 10 years, while the fathers were formally educated for 9 years on average. The stratum between 9 and 12 years of study presented the highest frequency in both variables related to level of education.

As for family income, most families (59.7\%) were in the stratum between 1 and 2 minimum wages, with only $10.2 \%$ families above this level, meaning that this population was characterized as being low income, a profile which is to be expected of preschoolers originating from public institutions.

Table 2 shows the results in absolute figures and percentage referring to the housing conditions of the children participating in the study. The data showed an average of six rooms per residence which, when making a ratio of rooms to people, shows an approximate average of one room per person.

With respect to the type of housing, masonry/brick houses were predominant (95.8\%), and only $4.2 \%$ of houses were made of rammed earth. In relation to power supply, $100 \%$ of dwellings had electricity. The water supply from the public network was $97.8 \%$ indoors and only $2.2 \%$ outside of the home. The result also showed that 100\% of homes were served by official garbage collection. It was noted with respect to sanitation that $88.7 \%$ of households were connected to public wastewater network and only $11.3 \%$ were served by a septic tank. In relation to the access roads, $53.5 \%$ of the families lived in regions with streets that were not paved.

Food consumption of the preschoolers is shown in Table 3 as percentages based on the responses given by the parents/guardians with regards to the foods consumed the most by the children.

We noted that the daily consumption of fruits and vegetables, chicken, eggs, beef liver, giblets and seafood was infrequent, which characterizes the presence of a monotonous diet, deficient in essential nutrients such as proteins of high biological value, vitamins, minerals, and unsaturated fatty acids essential for this growth phase.

We did not note the consumption of fast food in the group, probably because of the less favorable economic stratum and/or the age group in which they were found, which reduces access to this type of food.

Table 4 shows the results of the correlation between food consumption and nutritional status. It was observed that foods with a moderate positive correlation with risk of/excess weight were: soft drinks, butter and margarine, fried foods, coffee, pasta and artificial juices. Meanwhile, milk and dairy products, cookies, cakes, pies, sausages, breads and chocolate milk showed a strong correlation with risk and excess weight.

\section{Discussion}

In relation to birth weight, a similar study found a frequency of overweight that was $64 \%$ higher in children who had a birth weight $\geq 3.9 \mathrm{~kg} .{ }^{18}$ This suggests that the mean $(3.169 \mathrm{~kg})$ obtained in this study may have been a protective factor for the overweight condition.

A study with 1,544 children of public day care centers revealed a mean of 4.6 persons per household, ${ }^{19}$ a value close to that observed in our study. However, it indicated six years of maternal schooling and five years for the father, lower values than those found in our research.

The years of education of the mother were closer to the level verified in research assessing 132 children at day care centers in Rio de Janeiro, in the Brazilian state of Rio de Janeiro, which obtained a mean of $8.1( \pm 3.05)$ years of schooling. ${ }^{20}$ However, this was well above that reported in other studies assessing the prevalence and determinants of overweight among children and adolescents in the Brazilian state of Pernambuco, where the mean was four years of study for mothers. ${ }^{21}$

In our case, the time of formal education can be considered as relatively positive, given that we studied a low-income group, which creates the expectation of lower educational levels. There are discrepancies in the literature with regard to maternal education and the occurrence of overweight and obesity among children, given that such schooling increases the chances of parents entering the labor market, leading to increased family income. On the other hand, it is believed that a higher level of education can contribute by creating greater concern with the health of the child, including the encouragement of physical activity and consumption of healthier food, in addition to facilitating access to better quality foods. ${ }^{22}$

It is possible to note a positive association between the mother's level of education being greater than or equal to seven years of study and the occurrence of overweight among preschoolers. ${ }^{18} \mathrm{~A}$ study of 1,187 schoolchildren in Divinópolis, state of Minas Gerais, Brazil, showed that the children of mothers with more than eight years of study had a 1.62 (1.19-2.19) times greater chance of being overweight than those whose mothers had eight years of study or less. ${ }^{23}$

Several studies have shown that in economically less developed regions/states the proportion of obesity rises with increasing income, ${ }^{21,24,25}$ which may justify the absence of obesity among the target population researched. Corroborating these results, a study with children in this age 
TABLE 1 Characterization of the preschool children studied.

Variables

$\mathrm{N}$

$\%$

Mean (SD)

Statistics

Sex

Male

285

52.0

NS*

Female

263

48.0

Age (years)

Male

Female

285

263

52.0

$4.2(1.2)$

$\mathrm{NS}^{+}$

Birth weight (g)

Time of school enrollment (years)

548

48.0

4.1 (1.1)

$100.0 \quad 3,169(300)$

Weight (kg)

Male
Female

548

100.0

$1.5(0.1)$

285

52.0

$17.1(1.9)$

$\mathrm{NS}^{+}$

Height (cm)

Male

263

48.0

16.7 (1.5)

Female

285

52.0

$105.0(0.1)$

NS ${ }^{\dagger}$

General BMI

$<$ Z-score -3

263

48.0

$104.0(0.1)$

$-3<$ Z-score $<-2$

$\begin{array}{ll}0 & 0 \\ 13 & 2.4 \\ 467 & 85.2 \\ 45 & 8.2 \\ 23 & 4.2 \\ 0 & 0\end{array}$

$-2<$ Z-score $<+1$

$+1<$ Z-score $<+2$

$+2<$ Z-score $<+3$

$>$ Z-score +3

Boys' BMI

$<$ Z-score -3

$-3<$ Z-score $<-2$

0

$-2<$ Z-score $<+1$

11

247

87

$p<0.001^{\ddagger}$

$+1<$ Z-score $<+2$

$+2<$ Z-score $<+3$

$>$ Z-score +3

$16 \quad 6$

\section{Girls' BMI}

$<$ Z-score -3

$-3<$ Z-score $<-2$

$-2<$ Z-score $<+1$

$+1<$ Z-score $<+2$

$+2<$ Z-score $<+3$

$>$ Z-score +3

11

0

4

0

$\mathrm{p}<0.001^{\ddagger}$

Average number of family members

Mother's level of education (years)

$\leq 8$

9-12

$\geq 13$

0

2

220

29

12

0

$5.0 \pm 0.0$

213

213

23

Father's level of education (years)

$\leq 8$

9-12

239
240

$10.0(0.1)$
43.8

38.9

56.9

4.2

43.7
$\mathrm{P}<0.001^{\ddagger}$

11

0

$\mathrm{p}<0.001$

$9.0(0.1)$

$p<0.001^{\ddagger}$ 
TABLE 1 (Cont.) Characterization of the preschool children studied.

Variables

$\geq 13$

No information

Family's monthly income

\begin{tabular}{lll}
\hline$<1$ & 165 & 30.1 \\
\hline $1-2$ & 327 & 59.7 \\
\hline$\geq 3$ & 56 & 10.2
\end{tabular}

${ }^{*} \chi^{2}$ test; $\uparrow$ : Student's t-test; $\ddagger$ Kruskal-Wallis test; $5 \%$ significance level. NS: non significant; $<Z$-score -3 : extremely thin; $>Z$-score -3 and $<Z$-score -2 : thin; $>Z$-score -2 and $<Z$-score +1 : normal weight; $>Z$-score +1 and <Z-score +2 : risk of excess weight; $>Z$-score +2 and <Z-score +3 : excess weight; $>Z$-score +3 : obesity; BMI: body mass index.

\section{TABLE 2 Socioeconomic variables of the preschoolers' families.}

Variables

Rooms per residence

Type of residence

Rammed earth

Bricks/cement

Electricity

Yes

No

Public water supply

Indoors

Out of the house

Garbage collection

Yes

No

Public wastewate

Sewage

Septic tank

Paved street

Yes

No

Child was ill in the last 15 days

Yes

No

Symptoms presented

Diarrhea

Coughing

Fever

Control of parasitic diseases

Yes

No

Use of medication

Yes

No
$\mathbf{N}$

23

525

548

536

12

548

486

62

255

293

100

448

18.2

81.9

$\begin{array}{ll}8 & 8.0 \\ 33 & 33.0 \\ 59 & 59.0\end{array}$

$10 \quad 1.8$

$538 \quad 98.2$

$58 \quad 10.6$

490 


\section{TABLE 3 Percentage of food items consumed by preschoolers.}

\section{Food item}

Chocolate milk

Rice

Tapioca pancake, couscous

Wafers, cakes, sweet pies

Coffee

Broths and soups

Red meat

Poultry

Breakfast cereals

Chocolate and ice cream

Processed meats

Flours

Beans

Bovine liver

Fried food

Fruit

Vegetables

Yogurt

Milk and dairy products

Pasta

Butter and margarine

Giblets

Porridge

Egg

Bread

Seafood

Formula

Ham

Soft drinks

Artificial fruit juices

Natural fruit juices

Potatoes

Smoothies
Consumes

91.7

Does not consume

8.3

100.0

$\begin{array}{ll}79.5 & 20.5\end{array}$

94.1

5.9

78.9

21.1

$\begin{array}{ll}74.2 & 25.8\end{array}$

97.1

2.9

$87.4+12.6$

$\begin{array}{ll}77.8 & 22.2\end{array}$

$\begin{array}{ll}77.7 & 22.3\end{array}$

$83.3+16.7$

$\begin{array}{ll}72.4 & 27.6\end{array}$

$99.4 \quad 0.6$

$59.5 \quad 40.5$

$\begin{array}{ll}87.0 & 13.0\end{array}$

98.5

$75.9+14.1$

$\begin{array}{ll}86.9 & 13.1\end{array}$

$94.1 \quad 5.9$

$\begin{array}{ll}78.3 & 21.7\end{array}$

$95.4 \quad 4.6$

$39.2 \quad 60.8$

$\begin{array}{ll}61.8 & 38.2\end{array}$

$\begin{array}{ll}82.2 & 17.8\end{array}$

$98.5 \quad 1.5$

$\begin{array}{ll}73.6 & 26.4\end{array}$

$65.5 \quad 34.5$

$68.6 \quad 31.4$

$\begin{array}{ll}90.2 & 9.8\end{array}$

$82.8+17.2$

$89.8+10.2$

$\begin{array}{ll}76.1 & 23.9\end{array}$

$\begin{array}{ll}76.8 & 23.2\end{array}$ 
TABLE 4 Correlation between food consumption and nutritional status of the preschool children.

Consumption of food item

Nutritional status

\begin{tabular}{|c|c|c|c|}
\hline & Thin & Normal weight & Risk of/Excess weight \\
\hline & $\mathbf{r}^{2}$ & $r^{2}$ & $\mathbf{r}^{2}$ \\
\hline Rice & 0.236 & $0.657^{*}$ & 0.256 \\
\hline Beans & - & $0.721^{*}$ & 0.287 \\
\hline Fruit & - & $0.756^{*}$ & 0.143 \\
\hline Bread & - & 0.453 & $0.723^{*}$ \\
\hline Red meat & 0.218 & $0.856^{*}$ & 0.212 \\
\hline Butter, margarine & - & $0.687^{*}$ & $0.651^{*}$ \\
\hline Wafers, cakes, sweet pies & 0.298 & 0.489 & $0.832^{*}$ \\
\hline Milk and dairy products & - & $0.721 *$ & $0.854^{*}$ \\
\hline Chocolate milk & - & 0.218 & $0.722 *$ \\
\hline Soft drinks & - & 0.254 & $0.698^{*}$ \\
\hline Natural fruit juices & - & 0.465 & 0.176 \\
\hline Poultry & - & $0.854^{*}$ & 0.356 \\
\hline Fried food & - & 0.111 & $0.602^{*}$ \\
\hline Yogurt & - & $0.643^{*}$ & 0.231 \\
\hline Vegetables & - & $0.643^{*}$ & 0.115 \\
\hline Processed meats & - & $0.634^{*}$ & $0.754^{*}$ \\
\hline Artificial fruit juices & - & 0.287 & 0.376 \\
\hline Pasta & - & 0.367 & 0.432 \\
\hline Coffee & - & $0.898^{*}$ & $0.643^{*}$ \\
\hline Smoothies & - & 0.549 & - \\
\hline
\end{tabular}

group showed that children from families with an income of 2 to 3 minimum wages are twice as likely (OR 2.23, 95CI 1.34-3.72) to be overweight than those belonging to families with incomes of up to one minimum wage. ${ }^{26}$

Therefore, income is one of the factors that could encourage the consumption of healthier foods by increasing access to such, meaning that diet may be a protective factor for overweight. However, the most appropriate choices do not depend exclusively on income but also family eating habits, level of education, and the availability of time for the preparation of food, among others.

Considering monetary income as an indicator of Food and Nutrition Security (FNS), it is assumed that increased income may help to create a favorable environment for food security. ${ }^{27}$

The results of this study show that the excess weight of the children studied is well below the national average (36.4\%), ${ }^{3}$ as opposed to research where 578 children from public day care centers in the urban region of São Paulo, state of São Paulo, Brazil, were evaluated (intervention study), indicating the prevalence of a $28.9 \%$ risk of overweight and obesity. There was no significant difference when comparing different age strata. ${ }^{28}$ The research also noted a $20.8 \%$ risk of overweight, $5.2 \%$ overweight and $12.7 \%$ obesity in 403 preschoolers from the private education network in Teresina, state of Piauí, Brazil. ${ }^{29}$ Closer results were observed by researchers who assessed 1,435 children from the urban and rural zones of Pernambuco, Brazil, and determined a prevalence of $9.5 \%$ overweight and $3.8 \%$ obesity. ${ }^{21}$

The National Demography and Health Survey showed a prevalence of $7.8 \%$ of some degree of overweight among children aged under 5 years, associating this condition with the early introduction of foods, consumption of processed foods and sedentary lifestyle. ${ }^{30}$

In quilombo communities, a $6.0 \%$ prevalence of obesity was found by analyzing 724 children in the preschool age range from quilombo communities. ${ }^{31}$ The closest results to the present study were observed in research that indicated an $8.2 \%$ prevalence of overweight and $2.5 \%$ of obesity. ${ }^{32}$ Most studies show that overweight has a higher prevalence than obesity, with a variation in these results with respect to age group and sex. ${ }^{32,33}$ 
Considering that we studied children from all regions of the city, the results obtained are satisfactory with regard to housing conditions, given that almost the entire sample is served by basic services such as water supply, electricity and garbage collection, but insufficient basic sanitation. It is known that access to such services may influence the child's general health conditions and, therefore, their nutritional status.

In general, certain reasons for the results observed in this study may be proposed, including the improvement of population's living conditions, probably due to certain welfare programs, as well as greater access to healthcare. In addition to these, it is worth mentioning the protective effect due to the presence of these children in the day care centers, where the food provided must meet $30 \%$ of the daily nutritional requirements, distributed in at least two meals. ${ }^{34}$

The relationship between attendance at the day care center and the nutritional status of preschool children has been gaining interest in the current scenario, given that the children spend most of their day at such institutions, meaning that day care centers are responsible for providing most daily meals and, consequently, the supply of nutrients. ${ }^{26}$ In addition, these institutions no longer have merely a "supporting role" and have assumed an important function in child education, including the promotion of health actions that interfere in the nutritional status of preschool children.

The qualitative analysis of the children's diet does not allow us to infer about quantitative adequacy. However, it does enable an assessment of the diversity of the diet, given that it is known that a diversified diet is associated with greater quantitative adequacy, as it implies the intake of various nutrients.

The assessment of the usual consumption of food allows us to predict the risk that the consumption of certain foods can entail in the development of certain diseases, as it is possible to identify the cumulative effect of several nutrients simultaneously on health. ${ }^{35}$

According to Vilela et al., ${ }^{36}$ food choices are extremely important to proper growth and development because the quality and quantity of food ingested interferes with the supply of nutrients and nutritional status. The food consumption profile of the group under study was characterized by frequent intake of foods considered as traditional, such as "rice and beans," which is typical of the Brazilian culture, as well as other fundamental foods for appropriate child growth and development, such as milk and dairy products and red meat, which are important sources of protein, in addition fruits, which are sources of essential vitamins and minerals.

When analyzing which foods are consumed the most in Brazil, it was noted that those with the greatest frequency of use throughout the national territory and in all levels of family income were rice, beans, coffee, bread and beef, respectively. ${ }^{37}$ This data is in concordance with the results of this study with regard to the foods rice, beans, bread and red meat.

Similar results were observed in a study ${ }^{38}$ analyzing the dietary intake of public and private schoolchildren in São Luís, Brazil. The foods consumed the most were rice $(97.6 \%)$, bread $(77.6 \%)$, beans $(61.6 \%)$, butter/margarine $(61.1 \%)$, and beef $(59.6 \%)$.

Another unfavorable aspect observed in the diet of these children was the large number of children frequently consuming soft drinks to the detriment of the consumption of natural fruit juices and smoothies. Several reasons can be suggested as determinants, including convenience and lower cost. Excessive consumption of soft drinks and industrialized juices, foods with low levels of vitamins and minerals and high levels of additives and sugars, is a concern, given that drinks are capable of increasing the energy content of the diet and encouraging the emergence of obesity and related complications. ${ }^{39}$

The parents' choice of which foods to offer their children may be due to a lack of sufficient knowledge about the most important foods for the nutrition and development of these children and the association between the consumption of certain foods with social status and higher purchasing power because they are constantly exposed by the media.

In general, it could be said that this is not a very diversified diet, which can also be seen in a study that showed the consumption of a diet with little variety, with a high intake of cereals and low consumption of fruits, legumes and vegetables. ${ }^{31}$

Although ours is a low-income population, the vast majority of those responsible for the children reported the frequent consumption of food declared as being high cost. This fact is not in agreement with research that shows a trend of reduced consumption of foods such as meat, milk and dairy products, fruits, vegetables and legumes the lower the family income, due to the high cost of these foods. ${ }^{40}$

Data from the POF 2002-2003 further showed that lower income groups presented purchases of lower cost foods in order to achieve adequate caloric intake, such as oils, flours, cereals, cookies and soft drinks. This associa- 
tion is easily justified by the inverse correlation between the cost of food and its energy density. ${ }^{41}$

Research conducted with children using the public health network in Aracaju, Brazil, indicated high food consumption of cereals, meat, sugars, oils and fats and low consumption of fruits and vegetables. ${ }^{42}$ In the group under study it was also possible to note that the milk and dairy products food group was the one with the greatest share in the diet of this population, probably for dealing with children aged 6-35 months, a period where parents prioritize a milk-based diet, in the form of porridge, mash and purees. ${ }^{42}$

Considering the correlation between food consumption and nutritional status, a similar result was observed, especially the excessive consumption of soft drinks and artificial juices as risk factors for overweight in preschool age. ${ }^{18}$

On the other hand, studies show that the frequent consumption (three times per week) of fruits and vegetables showed a protective effect in the development of overweight and obesity, considering children between 5 and 9 years. ${ }^{43,44}$

For some authors, ${ }^{36,45}$ the study of the diet with various combinations of food rather than the consumption of individual food items or the intake of nutrients may be of greater interest, considering that foods are not consumed in isolation and reflect each individual's choice for a particular lifestyle.

\section{Conclusion}

The results of our study were positive regarding the prevalence of overweight and obesity among the group of preschoolers, showing prevalence well below the national average. In relation to food intake, it should be noted that the presence of some foods like cookies, cakes, pies and chocolate milk is more frequent than ideal, and these foods were declared by a large proportion of children. It is noteworthy that these are foods high in sugars, which undermines the concept of healthy eating and may favor the emergence of overweight and obesity.

Given these results, food and nutrition policies that encourage the consumption of healthy foods and maintain the consumption of basic traditional foods such as rice and beans are necessary, while at the same time encouraging a reduction in the consumption of processed foods that are high in sodium, saturated fat and simple sugars.

\section{ACKNoWledgments}

Thanks to the Coordination of Improvement of Higher Level Personnel (CAPES) for the master's degree scholarship awarded, the Municipal Department of Education, and the principals, professors, parents/guardians and children for their participation.

\section{Resumo}

Excesso de peso e obesidade em pré-escolares: prevalência e relação com consumo alimentar

Objetivo: Determinar a prevalência de excesso de peso e obesidade em pré-escolares de instituições públicas de ensino e sua relação com consumo alimentar.

Método: Estudo transversal com crianças de 2 a 5 anos, de ambos os sexos, atendidas em creches municipais. Coletaram-se dados socioeconômicos, demográficos e antropométricos, para cálculo do índice de massa corpórea (IMC) por idade. Os dados sobre consumo alimentar foram avaliados por meio de Questionário de Frequência Alimentar. Utilizaram-se os testes do $\chi^{2}$, Kruskal-Wallis, t de Student e correlação de Pearson, com nível de significância de 5\%. Resultados: Das 548 crianças, $52 \%$ eram do sexo masculino, com média de idade de 4,2 anos. A maioria das famílias apresentou renda entre 1 e 2 salários mínimos (59,7\%) e escolaridade materna de 10 anos. Os parâmetros antropométricos não apresentaram diferença significativa entre os sexos. Segundo o IMC/I, verificou-se que a maioria das crianças estava eutrófica (85,2\%); 8,2\%, com risco de excesso de peso; 4,2\%, com excesso de peso. Os alimentos mais consumidos foram: arroz (100\%), feijão $(99,4 \%)$, pães $(98,5 \%)$, frutas $(98,5 \%)$, carne vermelha $(97,1 \%)$, manteiga e margarina $(95,4 \%)$, bolachas, bolos, tortas doces $(94,1 \%)$, leite e derivados $(94,1 \%)$, achocolatado $(91,7 \%)$ e refrigerantes $(90,2 \%)$. Os alimentos consumidos que apresentaram forte correlação $(r>0,7)$ com o risco/excesso de peso foram: pães; bolachas, bolos, tortas doces; leite e derivados; achocolatados e embutidos.

Conclusão: Observaram-se baixa prevalência de excesso de peso e ausência de obesidade entre o público pesquisado. O risco de excesso de peso foi maior entre as meninas. $\mathrm{O}$ estudo mostrou desvios no consumo alimentar.

Palavras-chave: excesso de peso, obesidade, pré-escolar, consumo alimentar.

\section{References}

1. Xavier MO, Bielemann RM, Maciel FV, Neutzling MB, Gigante DP. Variação temporal no excesso de peso e obesidade em adolescentes de escola privada do Sul do Brasil. Rev Bras Atividade Física Saúde. 2014; 19(1):74-85

2. World Health Organization (WHO). Childhood overweight and obesity on the rise. Geneva: WHO; 2010.

3. Instituto Brasileiro de Geografia e Estatística (IBGE). POF 20082009 Antropometria e estado nutricional de crianças, adolescentes e adultos no Brasil. IBGE; 2010.

4. Antunes A, Moreira P. [Prevalence of overweight and obesity: in Portuguese children and adolescents]. Acta Med Port. 2011;24(2):279-84.

5. Hoare E, Fuller-Tyszkiewicz M, Skouteris H, Millar L, Nichols M, Allender S. Systematic review of mental health and well-being outcomes following 
community-based obesity prevention interventions among adolescents. BMJ Open. 2015; 5(1):e006586.

6. Caetano MC, Ortiz TT, Silva SG, Souza FI, Sarni SO. Complementary feeding inappropriate practices in infants. J Pediatr (Rio J). 2010; 86(3):196-201.

7. Owen CG, Martin RM, Whincup PH, Smith GD, Cook DG. Effect of infant feeding on the risk of obesity across the life course: a quantitative review of published evidence. Pediatrics 2005; 115(5):1367-77.

8. Spinelli MGN, Morimoto JM, Freitas APG, Barros CM, Dias DHS, Pioltine $\mathrm{MB}$, et al. Estado nutricional e consumo alimentar de pré-escolares e escolares de escola privada. Ciência \& Saúde. 2013; 6(2):94-101.

9. Silva JB, Silva FG, Medeiros HJ, Roncalli AG, Knackfuss MI. Estado nutricional de escolares do semi-árido do Nordeste brasileiro. Rev Saúde Pública. 2009; 11(1):62-71.

10. Cameron N. Anthropometric measurements. In: Cameron N, editor. The measurement of human growth. London: CroomHelm; 1984. p. 56-99.

11. Jelliffe DB, Jelliffe EFP. Community nutritional assessment with special reference to less technically developed countries. 2. ed. London: Oxford University Press; 1989.

12. World Health Organization. WHO child growth standards: Length/height-for-age, weight-for-age, weight-for-length, weight-for-height and body mass index-for-age. Methods and development. WHO (nonserial publication). Geneva: WHO; 2006.

13. Brasil. Ministério da Saúde. Secretaria de Atenção à Saúde. Departamento de Atenção Básica. Orientações para a coleta e análise de dados antropométricos em serviços de saúde: Norma Técnica do Sistema de Vigilância Alimentar e Nutricional - SISVAN / Ministério da Saúde, Secretaria de Atenção à Saúde, Departamento de Atenção Básica. Brasília: Ministério da Saúde; 2011.

14. World Health Organization - WHO, Anthro 2011 for Personal Computers Manual. Software for assessing growth and development of the world's children. World Health Organization; 2011.

15. Brandão SASM. Excesso de peso, obesidade, consumo alimentar e atividade física em pré-escolares de Teresina-PI. 2014 [dissertation]. Teresina: Universidade Federal do Piauí; 2014.

16. SPSS, Statistical Package for the Social Sciences - SPPS, versão 17.0; 2006

17. Andrade DF, Ogliori PJ. Estatística para as ciências agrárias e biológicas: com noções de experimentação. 2. ed. Florianópolis: Editora da UFSC; 2010. p. 470 .

18. Silveira JAC, Colugnati FAB, Cocetti M, Taddei JAAC. Secular trends and factors associated with overweight among Brazilian preschool children: PNSN-1989, PNDS-1996, and 2006/07. J Pediatr (Rio J). 2014; 90(3):258-66.

19. Shoeps DO, Abreu LC, Valenti VE, Nascimento VG, Oliveira AG, Gallo PR, et al. Nutritional status of pre-school children from low income families. Nutr J. 2011; 10:43.

20. Azevedo ECC, Dias FMRS, Diniz AS, Cabral PC. Consumo alimentar de risco e proteção para as doenças crônicas não transmissíveis e sua associação com a gordura corporal: um estudo com funcionários da área de saúde de uma universidade. Cienc Saúde Coletiva. 2014; 19(5):1613-22.

21. Leal VS, Lira PIC, Oliveira JS, Menezes RCE, Sequeira LAS, Arruda Neto MA, et al. [Overweight in children and adolescents in Pernambuco State, Brazil: prevalence and determinants]. Cad Saúde Pública. 2012; 28(6):1175-82.

22. Gopinath B, Baur AL, Burlutsky G, Robaei D, Mitchell P. Socioeconomic, familial and perinatal factors associated with obesity in Sydney schoolchildren. J Pediatrics Child Health. 2012; 48(1):44-51.

23. Souza MCC, Tibúrcio JD, Bicalho JMF, Rennó HMS, Dutra JS, Campos LG, et al. Fatores associados à obesidade e sobrepeso em escolares. Texto Contexto Enferm. 2014; 23(3):712-9.

24. Guedes DP, Miranda Neto JT, Almeida MJ, Silva AJRM. Impacto de fatores sociodemográficos e comportamentais na prevalência de sobrepeso e obesidade de escolares. Rev Bras Cineantropom Desemp Hum. 2010; 12(4):221-31.

25. Alencar MSS, Barros SEL, Borges IS, Cavalcante KN, Melo MTSM, Nunes IFOC et al. Adequacies and inadequacies in the anthropometric and dietetic profiles of preschool children. J Hum Growth Dev. 2016; 26(2):234-242.
26. Pereira AS, Peixoto NGA, Nogueira Neto JF, Lanzillotti HS, Soares EA. Estado nutricional de pré-escolares de creche pública: um estudo longitudinal. Cad Saúde Colet. 2013; 21(2):140-7.

27. Segall-Corrêa AM, Marin-Leon L, Helito H, Pérez-Escamilla R, Santos LMP, Paes-Sousa R. Transferência de renda e segurança alimentar no Brasil: análise dos dados nacionais. Rev Nutr. 2008; 21(Suppl 0):S39-51.

28. Nascimento VG, Silva JPC, Machado TC, Bertoli CJ, Valenti VE, Leone C. Preschool children and excess weight: the impact of a low complexity intervention in public day care centers. J Hum Growth Dev. 2013; 23(3):1-7.

29. Costa MJM, Araújo MLLM, Araújo MAM, Moreira-Araújo RSR. Excesso de peso e obesidade em pré-escolares e a prática de atividade física. Rev Bras Ciencia Mov. 2015; 23(3):70-80.

30. Brasil. Ministério da Saúde. Secretaria de Ciência, Tecnologia E Insumos Estratégicos - Departamento de Ciência e Tecnologia. Pesquisa Nacional de Demografia e Saúde da Criança e da Mulher - PNDS 2006 [Relatório]. Brasília: Ministério da Saúde; 2008.

31. Leite FMB, Ferreira HS, Bezerra MKA, Assunção ML, Horta BL. Consumo alimentar e estado nutricional de pré-escolares das comunidades remanescentes dos quilombos do estado de Alagoas. Rev Paul Pediatr. 2013; 31(4):444-51.

32. Pereira LL, Furlanetto C, Ferreira LM, Trespach SS, Silva MA, Ceretta LB Prevalência de sobrepeso e obesidade infantil entre lactentes, pré-escolares e escolares em uma área de abrangência do PET-SAÚDE. Arq Catarin Med. 2012; 41(4):9-14.

33. Simon VGN, Souza JMP, Leone CS, Souza SB. Prevalência de sobrepeso e obesidade em crianças de dois a seis anos matriculadas em escolas particulares no município de São Paulo. Rev Bras Cresc Desenvolv Hum. 2009; 19(2):211-8

34. Brasil. Ministério da Educação. Fundo Nacional de Desenvolvimento da Educação. Ministério da Educação. Resolução/CD/FNDE nº 26, de 17 de junho de 2013. Dispõe sobre o atendimento da alimentação escolar aos alunos da educação básica no âmbito do Programa Nacional de Alimentação Escolar - PNAE; 2013.

35. Nobre LN, Lamounier JA, Franceschini SC. Sociodemographic, anthropometric and dietary determinants of dyslipidemia in preschoolers. J Pediatr (Rio J). 2013; 89(5):462-9.

36. Vilela AAF, Sichieri R, Pereira RA, Cunha DB, Rodrigues PRM, Gonçalves-Silva RMV, et al. Dietary patterns associated with anthropometric indicators of abdominal fat in adults. Cad Saúde Pública. 2014; 30(3):502-10.

37. Souza AM, Pereira RA, Yokoo EM, Levy RB, Sichieri R. Alimentos mais consumidos no Brasil: Inquérito nacional de alimentação 2008-2009. Rev Saúde Pública. 2013; 47(1):190S-9S.

38. Conceição SIO, Santos CJN, Silva AAM, Silva JS, Oliveira TC. Consumo alimentar de escolares das redes pública e privada de ensino em São Luís, Maranhão. Rev Nutr. 2010; 23(6):993-1004.

39. Rampersaud GC, Bailey LB, Kauwell GPA. National survey beverage consumption data for children and adolescents indicate the need to encourage a shift toward more nutritive beverages. J Am Diet Assoc. 2003; 103(1):97-100

40. Panigassi G, Segall-Corrêa AM, Marin-León L, Pérez-Escamilla R, Maranha LK, Sampaio MFA. Insegurança alimentar intrafamiliar e perfil de consumo de alimentos. Rev Nutr. 2008; 21(Suppl 0):135s-44s.

41. Drewnowski A, Specter SE. Poverty and obesity: the role of energy density and energy costs. Am J Clin Nutr. 2004; 79(1):6-16.

42. Alves CRL, Santos LC, Goulart LMHF, Castro PR. Complementary feeding of children in the second year of life. Rev Paul Pediatria. 2012; 30(4):499-506

43. Enes CC, Slater B. [Obesity in adolescence and its main determinants]. Rev Bras Epidemiol. 2010; 13(1):163-71.

44. Oliveira AM, Cerqueira EM, Souza JS, Oliveira AC. [ Childhood overweight and obesity: influence of biological and environmental factors in Feira de Santana, BA]. Arq Bras Endocrinol Metab. 2003; 47(2):144-50.

45. Fisberg RM. A qualidade da dieta e seus fatores associados em adultos residentes no Estado de São Paulo [thesis]. São Paulo: Faculdade de Saúde Pública da USP; 2005. 